97 (507)

\title{
The development and function of the heart in embryos
} without nerves.

\author{
By DAVENPORT HOOKER. (By invitation.)
}

\author{
[From the Sheffield Biological Laboratory of Yale University, \\ New Haven, Conn.]
}

The somatic muscle in frog embryos, from which the cord has been removed, was proven by Harrison (1904) to develop and differentiate normally. Such muscle tissue, when stimulated by an extremely fine needle point, will contract provided the needle perforates the skin and penetrates the muscle itself. The response produces a single quick bending of the body toward the side stimulated, the point of stimulation being the center of contraction. Other experiments show that the muscle tissue cannot be stimulated through non-nervous protoplasmic connections.

In frog embryos from which the entire nervous system has been removed at the stage immediately following the closure of the neural folds, the heart functions normally. The rate is, however, slightly lower than in normal individuals. Microscopic examination shows that the cardiac muscle of such embryos has differentiated normally. The condition of this tissue very closely parallels the results obtained by Harrison in somatic muscle.

The results of these experiments show that, in the total absence of the nervous system, somatic muscle is directly irritable, the heart will function normally and cardiac muscle like somatic muscle will differentiate normally.

\section{$98(508)$ \\ The toxicity of amyl acetate.1}

By WILliam SALANT.

[From the Bureau of Chemistry, U.S. Department of Agriculture.]

From four to six cubic centimeters per kilo of amyl acetate injected into frogs caused paralysis and coma in from $\mathrm{r}_{5}$ to 30 minutes. These symptoms lasted 24 hours, with final recovery. In some cases such doses proved fatal. Larger doses were in-

${ }^{1}$ Published by permission of the Secretary of Agriculture. 